\title{
Incorporation and Originalist Theory
}

Lawrence B. Solum

Georgetown University Law Center, Ibs32@law.georgetown.edu

This paper can be downloaded free of charge from:

https://scholarship.law.georgetown.edu/facpub/861

http://ssrn.com/abstract=1346453

18 J. Contemp. Legal Issues 409-446 (2009)

This open-access article is brought to you by the Georgetown Law Library. Posted with permission of the author. Follow this and additional works at: https://scholarship.law.georgetown.edu/facpub

Part of the Constitutional Law Commons, Fourteenth Amendment Commons, Legal Theory Commons, and the Rule of Law Commons 


\title{
Incorporation and Originalist Theory $\dagger$
}

\author{
LAWRENCE B. SOLUM*
}

\section{TABLE OF CONTENTS}

I. INTRODUCTION: THE CHALLENGE OF INCORPORATION FOR ORIGINALIST THEORY

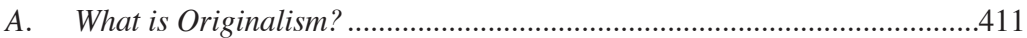

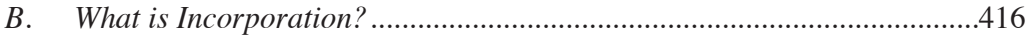

C. Narrowing the Scope of Inquiry to Privileges

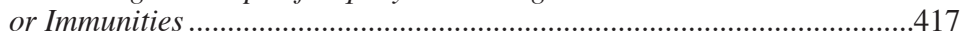

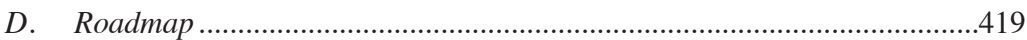

II. PUbliC MEANING OF “THE PRIVILEGES OR IMMUNITIES OF

Citizens of THE United STATES” FOR ORdinaRy CiTIZENS ................................419

A. Two Assumptions .......................................................................................419

1. Assumption One: "Original Meaning” Is Public

Meaning for Ordinary Citizens

$\dagger$ (C) 2009 by the author. Permission is hereby granted to duplicate this paper for scholarly or teaching purposes, including permission to reproduce multiple copies or post on the Internet for classroom use and to quote extended passages in scholarly work, subject only to the requirement that this copyright notice, the title of the article, and the name of the author be prominently included in the copy or extended excerpt. Permission is hereby granted to use short excerpts (500 words or less each, so long as the total word count of the excerpts does not exceed $50 \%$ of the total word count of this work) with an appropriate citation and without inclusion of a copyright notice. In the event of the death or permanent incapacity of the author, all claims to copyright in the work are relinquished and the work is dedicated to the public domain in perpetuity. Even if the author is then living, all copyright claims are relinquished as of January 1, 2050. In the event that the relinquishment of copyright is not given legal effect, an unlimited license of all rights to all persons for all purposes is granted as of that date.

* Associate Dean for Faculty and Research, John E. Cribbet Professor of Law, and Professor of Philosophy, University of Illinois College of Law. I owe thanks to Eric Claeys and Jason Mazzone for comments on an earlier draft. 
2. Assumption Two: Incorporation Must Be Justified by Interpretation Without the Aid of Construction

B. How Could Incorporation Be Justified as an

Interpretation Based on "Public Meaning" for

Ordinary Citizens?

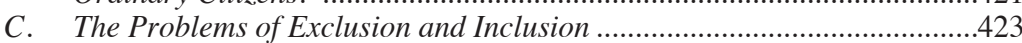

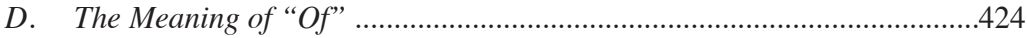

1. Privileges or Immunities that Any Citizen

of the United States Happens to Possess:

The All-rights Interpretation

2. Privileges or Immunities that Citizens

Possess by Virtue of the National Citizenship:

The In-Virtue-Of Interpretation

3. Privileges or Immunities that are Shared by

Citizens of the United States: The

Shared-Rights Interpretation...

4. Resolving the Ambiguity Regarding the Meaning of "Of"

III - "Privileges OR IMMUNITIES" AS A Term OF ART

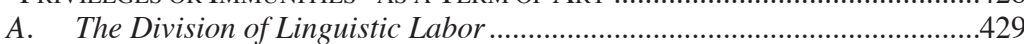

B. "Privileges or Immunities" as a Term of Art ...........................................431

1. Corfield v. Coryell .......................................................................432

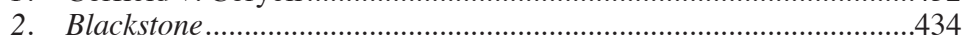

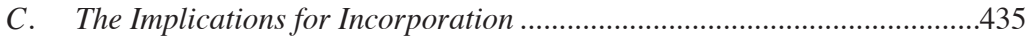

IV. CONSTRUCTION OF THE PRIVILEGES OR IMMUNITIES ClaUSE.................................436

A. The Interpretation-Construction Distinction Revisited ............................436

B. Incorporation and Vagueness ..................................................................4.438

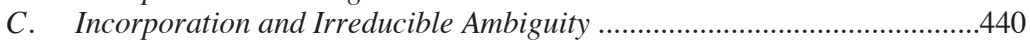

V. FAILURE OF CONSTITUTIONAL COMMUNICATION ...............................................442

A. Failure of Constitutional Communication in Theory ...................................442

B. The (Hypothetical) Case for the Failure of the

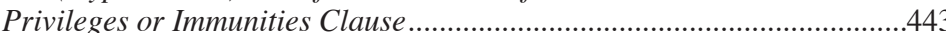

C. Incorporation as a Mending Construction ................................................444

VI. CONCLUSION: WHY INCORPORATION MATTERS FOR

ORIGINALISTS

\section{INTRODUCTION: THE CHALLENGE OF INCORPORATION FOR ORIGINALIST THEORY}

Does the Fourteenth Amendment of the United States Constitution incorporate the Bill of Rights contained in the first eight amendments? And how should an originalist answer that question? This paper focuses on the latter question - the issues of originalist theory that are raised by judicial and scholarly debates over what is called "incorporation." Before we dig into substance of the debate, we need to do some initial 
clarifying work by answering the questions, "what is originalism?" and "what is incorporation?"

\section{A. What is Originalism?}

The term "originalism" is itself disputed. ${ }^{1}$ Indeed, Thomas Colby and Peter Smith claim to have demonstrated "that, despite the suggestion of originalist rhetoric, originalism is not a single, coherent, unified theory of constitutional interpretation, but is rather a disparate collection of distinct constitutional theories that share little more than a misleading reliance on a common label." 2 At the other end of the spectrum, Mitch Berman claims that the term "Originalism" (with a capital "O") should be reserved for what he calls "Strong Originalism" - the view that the original meaning of the constitution should be the exclusive (or almost exclusive) determinant of constitutional meaning. ${ }^{3}$ Neither view is correct. Originalism is best viewed as a family of theories that characteristically affirm two theses:

The Fixation Thesis asserts that the linguistic meaning (or semantic content) of each constitutional provision was fixed at the time of origin (that is, the time at which each provision was framed and ratified).

The Contribution Thesis asserts that the semantic content of the Constitution contributes to the legal content of constitutional doctrine: ${ }^{4}$ characteristically, originalists claim that constitutional doctrine must be consistent with the "original meaning."

Although almost all self-identified originalists affirm some version of the fixation thesis and the contribution thesis, originalists have taken a

1. This Article utilizes many of the ideas that are developed in more depth and detail in Lawrence B. Solum, Semantic Originalism, (Ill. Pub. Law Research Paper No. 07-24, 2008), available at http://ssrn.com/abstract=1120244.

2. Thomas B. Colby \& Peter J. Smith, Living Originalism, 59 Duke L.J. 239 (2009).

3. Mitchell N. Berman, Originalism is Bunk, 84 N.Y.U.L. REV. 1, 17 (2009).

4. The phrase "constitutional doctrine" is used to refer to the content of articulated constitutional norms (in the broad sense that includes principles, standards, and rules in the narrow sense) - although doctrine might be limited to judicial doctrines, I use that term to encompass constitutional norms both inside and outside the court. I use the phrase "constitutional law" to encompass both "the Constitution" (the written document) and constitutional doctrine, but by this usage, I do not mean to make any metajurisprudential claims about the nature of law. 
variety of positions about the question as to what fixes original meaning and why original meaning does or should contribute to and constrain constitutional doctrine.

As to what fixes original meaning, originalist theory has evolved. In the contemporary period, early originalist theory emphasized the "original intentions of the framers." Later originalists emphasized the "original understandings of the ratifiers," and then the "original public meaning" of the constitutional text. Although the dominant strain of contemporary originalism emphasizes "public meaning," disagreement among originalists persist-with Richard Kay, ${ }^{5}$ Larry Alexander, ${ }^{6}$ Sai Prakash, ${ }^{7}$ Steven Smith, ${ }^{8}$ and others continuing to adhere to an intentionalist version of originalism. ${ }^{9}$ The gap between internationalism and public meaning may actually be quite narrow: because the relevant author of a constitution (i.e., the framers or ratifiers) is likely to have semantic intentions that point to public meanings, the conventional semantic meaning of the constitution and the intended meaning are likely to converge in most or even almost all cases. ${ }^{10}$

As to why original meaning should contribute to and constrain constitutional doctrine, originalists have advanced a variety of positions including:

Popular Sovereignty - some originalists have argued that the original meaning should constrain constitutional interpretation because the democratic legitimacy of the constitution derives from its ratification by democratic procedures: it was the "original meaning" that was authorized through such procedures. ${ }^{11}$

5. See Richard S. Kay, Original Intention and Public Meaning in Constitutional Interpretation, 103 Nw. U. L. REV. 703 (2009).

6. See Larry Alexander \& Saikrishna Prakash, "Is That English You're Speaking?" Why Intention Free Interpretation is an Impossibility, 41 SAN DIEGO L. REV. 967, 98081 (2004).

7. See id.

8. See Steven D. Smith, Law's QuAndary 122-23, 125 (Harv. Univ. Press 2004).

9. See Lawrence B. Solum, 103 District of Columbia v. Heller and Originalism, Nw. U.L.REV. 923 (2009) (summarizing the development of originalist theory). The case against intentionalism is made in detail in Semantic Originalism, supra note 1.

10. Convergence will depend on the particular form of original-intentions originalism. If the relevant intentions are "semantic intentions" (intentions concerning the linguistic meaning of the constitutional text), then the argument for convergence in text goes through. But if the relevant intentional states are purposes, motives, or expectations, then originalintentions originalism and original-meaning originalism will diverge in a wide variety of cases.

11. See Kurt Lash, Originalism, Popular Sovereignty, and Reverse Stare Decisis, 93 VA. L. ReV. 1437, 1440 (2007). But see Saikrishna B. Prakash, The Misunderstood Relationship between Originalism and Popular Sovereignty, 31 HARV. J.L. \& PUB. POL'Y 485, 486 (2008). 
Writtenness-other constitutional theorists have argued that the authority of the original meaning is entailed by the fact that the Constitution is written: the point or purpose of writtenness is to fix and constrain the content of constitutional doctrine. ${ }^{12}$

Supermajoritarianism-and still other originalists have emphasized the notion that the original meaning of the Constitution was adopted through supermajoritarian procedures that produce legal rules with better consequences than legal rules that are not adopted through such procedures. ${ }^{13}$

The Rule of Law - another argument for originalism emphasizes the constraining force of fixed semantic content and the predictability, certainty, and stability that such constraint fosters; ${ }^{14}$ the flip side of this argument is the originalist critique of the discretion conferred by constitutional practice that allows judges to engage in constitutional practice that resorts to the judge's own beliefs about fundamental values.

Legal Practice - and finally, some originalists argue that the conventions of legal practice recognize that the linguistic meaning of the Constitution constrains officials who engage in constitutional practice, including the Justices of the Supreme Court: fidelity to law requires adherence to such practices absent the extraordinary conditions that warrant official lawlessness. ${ }^{15}$

For the most part, this Article will operate within the framework of what has been called "the New Originalism"16 or "original public meaning originalism." That is, the discussions of originalist theory will begin with the assumption that the "original meaning of each constitutional

12. See generally Andrew B. Coan, The Irrelevance of Writtenness in Constitutional Interpretation (Oct. 8, 2008) (unpublished manuscript, available at http://ssrn.com/abstract $=1281066$ ) (discussing and criticizing argument from writtenness).

13. See John McGinnis \& Michael Rappaport, Our Supermajoritarian Constitution, TEXAS L. REV. (forthcoming), available at $\mathrm{http}: / / \mathrm{ssrn}$.com/abstract=288344.

14. See Jack M. Balkin, Original Meaning and Constitutional Redemption, 24 Const. Comment. 427, 429 (2007); Randy E. Barnett, Trumping Precedent With Original Meaning: Not As Radical As It Sounds, 22 Const. Comment. 257, 259 (2005); Steven G. Calabresi \& Saikrishna B. Prakash, The President's Power To Execute the Laws, 104 YALE L.J. 541, 551-52 (1994).

15. I argue for this conclusion in Semantic Originalism, supra note 1.

16. Keith Whittington, The New Originalism, 2 GeOrgetown J. L. \& PuB. Pol'y 599 (2004). 
provision" was fixed at the time of origin by conventional semantic meaning of the words and phrases and by the conventions of syntax and grammar at the time that the provision in question was framed and ratified. But that starting assumption may be incomplete or partial. For example, it is possible that the constitutional text includes "terms of art," words or phrases like "letters of marquee and reprisal" or "natural born citizen" which lacked a "public meaning" for ordinary citizens but which, via a division of linguistic labor, had a conventional semantic meaning fixed by the usage of a linguistic subgroup (e.g., those learned in the law). ${ }^{17}$

In addition, this Article adopts the distinction between "original meaning" and "original applications" or "original expected applications." The phrase "original expected applications" originates with Jack Balkin, ${ }^{18}$ but Mark Greenberg and Harry Litman articulated a similar distinction between "original meaning" and "original expectations" in their important 1998 article, The Meaning of Original Meaning. ${ }^{19}$ The point of the distinction is that the linguistic meaning (or semantic content) of a text is not the same as expectations about the application of that meaning to future cases. Accepting this distinction does not imply that evidence about expected applications is not relevant (epistemically) to the determination of the conventional semantic meaning of the constitutional text: expected applications of a text may offer evidence about its meanings. Rather, the implication is that expectations about applications are neither decisive evidence of meaning nor meaning itself.

Moreover, the version of originalist theory that serves as the baseline for the discussion will embrace the distinction between "constitutional interpretation," understood as the enterprise of discerning the linguistic meaning or semantic content of the Constitution, and "constitutional construction," which we might tentatively define as the activity of further specifying constitutional rules when the original public meaning of the text is vague or underdeterminate. ${ }^{20}$ This distinction explicitly

17. See Solum, supra note 1.

18. See Jack Balkin, Abortion and Original Meaning, 24 Const. Commentary 291, 295-26 (2007); Jack Balkin, Original Meaning and Constitutional Redemption, 24 CONST. COMMENT. 427, 448 (2008); Posting of Jack Balkin to Balkinization, http://balkin. blogspot.com/2007/07/clarence-thomass-originalism.html (July 11, 2007, 10:11 EST); Jack Balkin, Alive and Kicking, YALE LAw SCHOOL, Sept. 19, 2005, http://www.law.yale.edu/ news/1846.htm; see also Jack Balkin, Framework Originalism and the Living Constitution, 103 Nw. U. L. REV. 549 (2009).

19. Mark Greenberg \& Harry Litman, The Meaning of Original Meaning, 86 GEO. L.J. 569, 573-74 (1998).

20. The distinction is strongly associated with Randy Barnett and Keith Whittington. RANDY BARNETT, RESTORING THE LOST CONSTITUTION 88 (2004); KeITH WhitTINGTON, CONSTITUTIONAL INTERPRETATION 5 (1999); Keith WhitTington, CONSTITUTiOnAl 
acknowledges what we might call the fact of constitutional underdeterminacy. ${ }^{21}$ The linguistic meaning of the Constitution does not provide fully determinate answers to all the possible or actual questions that could be or have been raised. Characteristically, originalist theory asserts that the doctrines of constitutional law that are articulated to resolve such underdeterminacies must be consistent with the linguistic meaning of the constitutional text, but stronger or weaker variations are possible.

Finally, the fact of constitutional underdeterminacy that motivates the distinction between "interpretation" and "construction" can be clarified by distinguishing between "vagueness" and "ambiguity." The terms "vague" and "ambiguous" are used in both precise and imprecise senses. In loose talk, "vague" and "ambiguous" are sometimes treated as synonyms or as different degrees of underdeterminacy. ${ }^{22}$ This Article will use the terms "vague" and "ambiguous" in their strict (or philosophical) senses ${ }^{23}$ as articulated in the following definitions:

Vagueness: A term or phrase is vague if and only if it admits of borderline (or uncertain) cases. ${ }^{24}$

Construction 5 (1999); Randy E. Barnett, An Originalism for Nonoriginalists, 45 LOYOLA L. REV. 611, 611-29 (1999). Another important early adopter of this distinction (in the context of constitutional theory) was Robert Clinton. See Robert N. Clinton, Original Understanding, Legal Realism, and the Interpretation of 'This Constitution', 72 IOWA L. REV. 1177, 1265 (1987). For a brief introduction to the distinction, see Legal Theory Lexicon 063: Interpretation and Construction, http://solum.typepad.com/legal theory_lexicon/2008/04/legal-theory-le.html (Feb. 8, 2009).

21. See Posting of Lawrence B. Solum to Legal Theory Blog, http://lsolum. typepad.com/legaltheory/2007/10/semantic-and-no.html (Oct. 30, 2007, 12:30). $C f$. Lawrence B. Solum, On the Indeterminacy Crisis: Critiquing Critical Dogma, 54 U. CHI. L. REV. 462, 473 (1987) (distinguishing determinacy, indeterminacy, and underdeterminacy).

22. Ambiguity is sometimes defined as having two senses: the first is "doubtful or uncertain" and the second is "capable of being understood in two or more possible senses." Merriam-Webster Online Dictionary, http://www.m-w.com/dictionary/ambiguous. Vague is defined as unclear or imprecise. Merriam-Webster Online Dictionary, http://www. $\mathrm{m}$-w.com/dictionary/vague. Neither ordinary usage nor the dictionary definitions capture the strict (or philosophical) senses of these terms.

23. See Legal Theory Lexicon 051: Vagueness and Ambiguity, http://lsolum. typepad.com/legal_theory_lexicon/2006/08/legal_theory_le.html (Nov. 22, 2008).

24. A deeper account is offered in TimOTHY A.O. ENDicotT, VAGUENESS IN LAW (Oxford: Clarendon, 2000). Endicott identifies two marks of vagueness: (1) borderline cases, (2) a tolerance principle, which states that "a tiny change in an object in a respect relevant to the application of the expression cannot make the difference between the expression's applying and not applying." Id. at 31-33. 
Ambiguity: A term or phrase is ambiguous in the strict or philosophical sense when it has more than one sense or meaning. ${ }^{25}$

The term "tall" is vague in the strict sense. Some people are definitely short-Danny DeVito. Others definitely are tall-Shaquille O'Neal. But the term "tall" is vague. 5' 11 is almost definitely tall for a woman in the United Sates, but it is probably a borderline case for men-Kurt Russell (in real life) is neither definitely tall nor definitely not tall. "Tall" is not the sort of quality for which there are definite criteria that sort the world into "tall" things and "not tall" things. In other words, "tall" is vague. "Cool," on the other hand, is ambiguous, because it has one sense related to temperature, another sense related to excitement and emotion, and a third sense related to hipness and style. ${ }^{26}$ The same term or phrase can be both vague and ambiguous: for example, when "cool" is used to refer to temperature, it is vague, because there is no bright line between warm and cool.

In sum, an originalist theory is a member of the family of theories of constitutional interpretation that claims: (1) that the linguistic meaning of each provision of the constitution was fixed at the time that provision was framed and ratified, and (2) that the original meaning constrains correct or legitimate constitutional practice. Originalist theories include original intentions originalism and original public originalism, and these theories have been justified by a variety of arguments, including arguments that focus on popular sovereignty and the rule of law. Many originalists distinguish constitutional interpretation (which recovers the linguistic meaning of the text and resolves ambiguity) from constitutional construction (which characteristically involves the determination of constitutional doctrines and practices that deal with underdeterminacies that result from the fact that many constitutional provisions are vague).

\section{B. What is Incorporation?}

Articulating the implications of originalist theory for incorporation requires an understanding of "incorporation." There is a widely shared "rough and ready" understanding of incorporation - a provision of the Bill of Rights is "incorporated" if that provision is applied to the states; mutatis mutandus, such provisions are "not incorporated" if they are not

25. For discussions of ambiguity, see Michael B. Rappaport, The Ambiguity Rule and Insurance Law: Why Insurance Contracts Should Not Be Construed Against the Drafter, 30 GA. L. REV. 171, 178-87 (1995); Allan Farnsworth, "Dmeaning” in the Law of Contracts, 76 Yale L.J. 939, 953-57 (1967); John T. Valauri, Confused Notions and Constitutional Theory, 12 N. Ky. L. ReV. 567, 570-73 (1985).

26. Merriam-Webster Online Dictionary, http://www.m-w.com/dictionary/cool. 
applied to the states. But this rough and ready understanding is imprecise for at least two reasons. First, incorporation does not necessarily involve the application of the semantic content of the first eight amendments to the Constitution to the states. For example, the First Amendment begins "Congress shall make no law ...," but the incorporation debates are not about the powers of Congress - they are about the application to the states of the substance of "establishment," "free exercise," "freedom of speech," and so forth. ${ }^{27}$ The second reason that the rough and ready formulation is imprecise is related to the first reason. Despite Barron v. Baltimore, ${ }^{28}$ the Bill of Rights has always applied to the states. State courts have always been bound by limitations of federal power in the Bill of Rights. State legislatures have never had the power to authorize Congress to infringe the freedom of speech; nor have state executives ever had the power to enforce federal laws that would violate the freedom of the press. The first and second reason both establish that the incorporation debate is about application of the rights established by the doctrines of constitutional law that are associated with the Bill of Rights as limitations of state power that parallel the limitations these rights impose on the federal government.

Both constitutional doctrine and theoretical debate about incorporation have followed a tortuous path-with many twists and turns. In particular, one aspect of the debate concerns the extent to which incorporation is wholesale or selective. Is the entirety of the Bill of Rights to be applied to the states? Or are some provisions to be included (freedom of speech) and others omitted (the right to bear arms)? Another twist concerns the content of the rights that are to be incorporated. If the "freedom of speech" is incorporated, does this imply that the limitations on state power are "identical" (in a loose sense of "identical") to the limitations on federal power imposed by the First Amendment? Or does incorporation only require that some subset of these limitations be imposed on the states - perhaps the "core"?

\section{Narrowing the Scope of Inquiry to Privileges or Immunities}

The general topic at hand is investigation of the implications of

27. Michael Kent Curtis articulates this point in terms of the distinction between rights and security devices. See Michael Kent Curtis, The Bill of Rights and the States: An Overview From One Perspective, 18 J. CONTEMP. Legal Issues 3 (2009).

28. Barron v. Mayor of Baltimore, 32 U.S. 243, 250-51 (1833). 
originalist theory for debates about incorporation of the Bill of Rights via the Fourteenth Amendment. In theory such incorporation might be accomplished via "equal protection," "due process," or "privileges or immunities." And in practice, the focus of current constitutional doctrine has been on the due process clause. For the purposes of this Article, however, discussion will focus on the privileges or immunities clause of Section One.

This is only an assumption. This Article does not claim that something like incorporation could not be justified by originalist interpretation of the due process clause or the equal protection clause. Perhaps, "due process of law" implies that the "law" reflected in the Bill of Rights is "due," or perhaps the rights established in the first eight amendments are components of "liberty" that the due process clause protects. These possibilities will simply be set aside, and this Article will proceed on the assumption that the due process clause is limited to what we call "procedural due process." Likewise, it is possible that the phrase "equal protection of the laws" includes "protection by the rights established in the "laws" set forth in the Bill of Rights." Once again, I shall simply assume that the equal protection clause is either concerned with substantive equality (the conventional understanding embodied in modern doctrine) or with the equal enforcement of the legal rights of all persons (as an originalist might argue).

Incorporation under the privileges or immunities clause might have important practical consequences. The due process and equal protection clauses apply to all "persons" whereas the privileges or immunities clause applies only to "citizens of the United States." So, if the Supreme Court were to transfer the basis of incorporation to the latter clause, the structure of legal rights of noncitizens would be changed in various ways. This practical question is surely important, but it will not receive further attention in this article. ${ }^{29}$

If we set aside the due process and equal protection clauses, we are left with the privileges or immunities clause:

No State shall make or enforce any law which shall abridge the privileges or immunities of citizens of the United States.

Thus, a first take on our question could be framed as follows: are the substantive rights (freedom of speech, free exercise, the right to keep and bear arms) set out in the Bill of Rights "privileges or immunities citizens of the United States" given the conventional semantic meaning of that phrase (or its constituent elements) at the time of the framing and

29. See Solum, supra note 1. 
adoption of the Fourteenth Amendment?

\section{Roadmap}

With our question now defined, the remainder of this Article will proceed as follows. Part II examines the theoretical framework for an investigation of incorporation that operates within the narrow confines of interpretation of the text based on the assumption that the original meaning of the text is solely determined by the public meaning for ordinary citizens at the time of framing and ratification. Part III relaxes the assumption that "original meaning" is determined solely by the linguistic practices of the whole community and considers the possibility that the phrase "privileges or immunities" was a term of art with a technical meaning for those learned in the law. Part IV relaxes the assumption that the incorporation debate must be resolved solely by interpretation and considers the possibility that incorporation doctrine might be viewed as a construction of an underdeterminate constitutional text. Part V considers the implications of the possibility that the "privileges or immunities clause" instantiates what might be called a failure of constitutional communication. Part VI concludes.

\section{PUbliC MEANing OF “THE PRIVILEGES OR IMMUNities OF Citizens OF THE UNITED STATES” FOR ORDINARY CITIZENS}

This Article is about the relationship of originalist theory to the incorporation debate. The point of the Article is to pinpoint the theoretical assumptions that are implicit in various moves that are (or could be) made by those who advocate or oppose incorporation on originalist grounds. In order to lay bare the theoretical bones, the assumptions of originalist theory will be articulated as carefully defined assumptions. The aim is to isolate the effect of the various elements of (and options for) originalist theory. That isolation begins with two assumptions - about "public meaning" and "interpretation."

\section{A. Two Assumptions}

This Part is predicated on two assumptions (which are relaxed in subsequent Parts of this Article): first, that original meaning is limited to public meaning for "ordinary citizens," and second, that incorporation must be justified on the basis of interpretation without the aid of 
construction. Each of these assumptions requires further explanation.

\title{
1. Assumption One: "Original Meaning” Is Public Meaning for Ordinary Citizens
}

The first assumption is that "original meaning" should be understood as meaning for the public at large or for "ordinary citizens." This assumption is explicit in the following passage from the majority opinion in District of Columbia v. Heller:

\begin{abstract}
In interpreting this text, we are guided by the principle that " $[\mathrm{t}]$ he Constitution was written to be understood by the voters; its words and phrases were used in their normal and ordinary as distinguished from technical meaning." United States v. Sprague, 282 U.S. 716, 731, 51 S.Ct. 220, 75 L.Ed. 640 (1931); see also Gibbons v. Ogden, 9 Wheat. 1, 188, 6 L.Ed. 23 (1824). Normal meaning may of course include an idiomatic meaning, but it excludes secret or technical meanings that would not have been known to ordinary citizens in the founding generation. 30
\end{abstract}

In this passage, Justice Scalia distinguishes between "idiomatic meaning" and "technical meanings." The notion of an idiom is based on the fact a phrase in a natural language such as English can have a meaning that is not identical to the meaning that would be derived from the individual words and the rules of grammar and syntax via the principle of compositionality. A "nest egg" is not an egg in a nest. Someone who "kicks the bucket" is dead-and most definitely not "alive and kicking." Heller allows for the idiomatic meanings, but it rejects "technical meanings" "that would not have been known to ordinary citizens in the founding generation."

Underlying this assumption are further assumptions about patterns of linguistic practice. Ordinary citizens participate in a general community of language users. Not every citizen knows the meaning of every word or phrase that has what Heller calls "normal meaning"-but for a meaning to be "normal" it must be widely dispersed culturally (among various social and occupational groups) and geographically in the relevant community (defined by the territory of the United States) ${ }^{31}$ "Technical meanings" are shared by linguistic subgroups, e.g. lawyers, doctors, or seamen, whose linguistic communities have distinctive patterns of usage that are not shared by the general community of language users.

For the purposes of this Part, we shall assume that the original

30. District of Columbia v. Heller, 128 S. Ct. 2783, 2788 (2008).

31. The explanation in text is not intended as an adequate theory of "normal meaning": it is a gesture or "hand wave" in the direction of a more fully developed account. "Normal meaning" is Justice Scalia's term. Scalia's terminology plays no role in the theory I develop in Semantic Originalism, supra note 1. 
meaning of the privileges or immunities clause is the conventional semantic meaning of the phrase "the privileges or immunities of citizens of the United States" for the community of competent English speakers who occupied the territory of the United States.

\section{Assumption Two: Incorporation Must Be Justified by Interpretation Without the Aid of Construction}

Recall that the interpretation-construction distinction differentiates two distinct modes or moments in the application of the constitutional text to a particular case or controversy. Constitutional interpretation discovers the linguistic meaning or semantic context of the text. Constitutional construction translates that meaning into constitutional doctrines that are sufficiently determinate to resolve particular cases. In some cases, construction is automatic - the constitutional text assigns two Senators to each state and this content of the corresponding rule of constitutional doctrine is identical to the linguistic meaning of the text in all but the most unusual circumstances. But in other cases, the linguistic meaning may be vague. For example, the phrases "legislative power," "executive power," and "judicial power" may have a core of determinate meaning but admit of borderline cases that require a rule of construction to resolve particular questions.

For the purposes of this Part, we shall operate on the assumption that the question whether the privileges or immunities clause authorizes incorporation should be answered in the affirmative if and only if incorporation is required by constitutional interpretation - that is, by the linguistic meaning of the clause without supplementation by constitutional construction.

\section{B. How Could Incorporation Be Justified as an Interpretation Based on "Public Meaning" for Ordinary Citizens?}

Much of the discussion surrounding incorporation and the privileges or immunities clause is framed in intentionalist terms. Did the framers (or ratifiers) of the Fourteenth intend to incorporate the Bill of Rights? Was that their purpose? Did they expect that incorporation would follow from adoptions of the Fourteenth? Given the two assumptions that control the discussion in this Part, the answers to those questions can only provide indirect evidence that bears on the main questionwhat was the conventional semantic meaning (or "normal meaning") of 
the phrase "privileges or immunities of citizens of the United States" for ordinary citizens?

To begin, it is obvious that the privileges or immunities clause does not directly and unambiguously state that the states may not violate the rights of citizens that are contained in the Bill of Rights. That could have been said in various ways. Each provision of the Bill of Rights could have been repeated with an appropriate adjustment: for example, "No state shall violate the free exercise of religion or infringe the freedom of speech." Or the clause could have read, "No State shall make or enforce any law which shall abridge the privileges or immunities of citizens of the United States as defined by the first eight amendments to this Constitution."

Nonetheless, it has been argued that the privileges and immunities clause should be read as having semantic content that is functionally equivalent to a direct and unambiguous statement of incorporation. Consider the following passage from Michael Kent Curtis's Article for this conference:

\footnotetext{
According to Felix Frankfurter (concurring in Adamson v. California and citing Justice Holmes), "an amendment to the Constitution should be read in a 'sense most obvious to the common understanding at the time of its adoption. . . . . For it was for public adoption that it was proposed."' What follows is a common, natural, and direct reading of the privileges or immunities clause:

No state shall make or enforce any law which shall abridge [reduce in scope or diminish] the privileges [rights] or immunities of [shared by and secured to] citizens of the United States.

Of course, the security was incomplete, as Barron v. Baltimore established. That is why the additional "no state shall" security was needed. One logical place to look for rights of citizens of the United States would be the rights set out in the Constitution. The major group of rights listed is those liberties in the Bill of Rights. There are a number of others such as habeas corpus. Does the Bill of Rights contain rights? We do describe it as a "Bill of Rights." The rights are declared to exist, sometimes explicitly, sometimes implicitly. However, as the Supreme Court ruled in Barron, the rights are secured only against federal invasion. ${ }^{32}$
}

The key premise in Curtis's argument is that the words "privilege" and "immunity" were used as synonyms for the words "right" and "liberty," and that the rights conferred in the Bill of Rights were described as "privileges" and "immunities" in ordinary usage in the periods before, during, and after the framing and ratification of the Fourteenth Amendment. Much of the evidence is provided in other work by Curtis that is cited in his paper for this conference. ${ }^{33}$

32. Curtis, supra note 27.

33. See, e.g., Michael Kent Curtis, Historical Linguistics, Inkblots, and Life after Death: The Privileges or Immunities Of Citizens Of The United States, 78 N.C. L. Rev. 
Let us assume that Curtis is right about linguistic practice in the relevant period, and that the rights conferred by the Bill of Rights would have been understood as "privileges" and "immunities" as well as "rights" and "liberties." (For the record, let me state that based on my reading of Curtis and other secondary literature, but not the original sources, I am provisionally persuaded by Curtis on this point.) Would this make the case for incorporation given the two assumptions (public meaning only and interpretation solely)? That question takes us to the problems of exclusion and inclusion.

\section{The Problems of Exclusion and Inclusion}

If we assume that the phrase "privileges or immunities" is the equivalent of "rights or liberties" or more simply "rights," does this imply that the privilege or immunities clause incorporates the "rights" in the Bill of Rights? The problem with answering this question is that we need first to solve problems of exclusion and inclusion - what rights are included and what rights are excluded. The semantic content of the clause is sufficient, by itself, to support the conclusion that at least some rights must be included-otherwise the clause would be without legal effect. One possible reading of the clause is that "all rights" are protected-this might flow from the use of the definite article "the" preceding "privileges or immunities." The use of the definite article "the" and the preposition "of" may imply that the rule of inclusion is existence - all rights that citizens have are included: the corresponding rule of exclusion is nonexistencerights that citizens do not possess are excluded. ${ }^{34}$

But this immediately leads to another question, what kind of rights? This question will quickly lead us into deep waters and myriad possibilities. On this occasion, I will evade my responsibility for "doing the right thing" by investigating all of the possibilities and their merits and instead I shall merely assume that there are only three relevant possibilities. The concept of right is ambiguous as between two kinds: legal rights (the rights conferred by law) and moral rights (the rights that citizens have a

1071, 1091 (2000). This article is essential reading for anyone researching the original meaning of the privileges or immunities clause.

34. The definite article "the" implies that the thing referred to is a particular thing: the function of the definite article is to particularize. So the phrase "the privileges or immunities" has a different meaning than would the phrase "some privileges or immunities" or the phrase "a privilege or immunity." 
matter of political morality - alternatively we could use the terminology "natural rights"). Thus, "privileges" or "immunities" might refer to: (1) legal rights only, (2) moral rights only, or (3) both moral and legal rights.

For the moment, let us assume (as Curtis seems to assume) that the Fourteenth Amendment refers only to legal rights. (Notice that this assumption leaves open the possibilities that legal rights are justified by reference to moral rights or that the two categories are extensionally equivalent or nearly equivalent.) The assumption that privileges or immunities are legal rights then yields the conclusion that the privileges or immunities clause encompasses all of the legal rights that citizens actually possess, including but not limited to the rights contained in the Bill of Rights.

That conclusion would be troubling for obvious reasons. It would entail the conclusion that the privileges or immunities clause conferred constitutional status (as against the states) on all the legal rights possessed by citizens, including for example, all of the rights under state law including the provisions of contracts, wills, trusts, and so forth. There is much more to be said about this possibility, but at this point we can merely observe that this interpretation of the privileges or immunities clause is very broad and might even count as "absurd"although much would need to be said to show that was so.

If moral rights were included, the implications would be even more disturbing. If all moral rights were protected by the Privileges or Immunities Clause, then the Fourteenth Amendment would prevent the states from doing anything that violated any justified moral claim of any citizen. Because lawmaking is state action, the implication is that every state law would be subject to a "morality" test-federalizing the regulation of almost every aspect of human conduct.

\section{The Meaning of "Of"}

But there is more text! The relevant phrase is "privileges or immunities of citizens of the United States." What does it mean for a right to be a right of citizens of the United States? There are at least three possibilities - although there may be more.

\section{Privileges or Immunities that Any Citizen of the United States Happens to Possess: The All-rights Interpretation}

The first possibility is that the word "of" limits "privileges or immunities" to those rights that any citizen of the United States happens to possess. In the immediately prior section, we discussed the problems 
that this reading creates. Because it results in the constitutionalization of all legal rights possessed by any citizen of the United States, any time any state acted in a way that modified or extinguished a legal and/or moral right, there would potentially be a violation of the Fourteenth Amendment. This reading seems implausible.

\section{Privileges or Immunities that Citizens Possess by Virtue of the National Citizenship: The In-Virtue-Of Interpretation}

A second possibility is that for a right to be a privilege or immunity of citizens of the United States, the right must be a right that the citizen possesses qua (or in virtue of) United States Citizenship. That is, the right must be a right that the person does possess because the person is a citizen and that the person would not possess if the person were not a citizen. Rights that are limited to citizens would be included, and rights that are not limited to citizens would not be included. This rule would result in the exclusion of a variety of rights conferred by state and federal law on citizens and noncitizens alike. For example, it would exclude various common law rights and rights created by contracts, trusts, and the like. It would also exclude a variety of statutory rights, both state and federal-such as the rights conferred by copyright, patent, and trademark statutes (because these rights do not depend on one's status as a citizen).

How would this principle operate with respect to the Bill of Rights? Some of the rights that are included in the Bill of Rights may be limited to United States Citizens. For example, the Second Amendment recognizes "the right of the people to keep and bear arms," and arguably "the people" refers to citizenry rather than all persons: a similar observation could be made about the right of assembly in the First Amendment. But other provisions of the Bill of Rights are not limited in this way. The Third Amendment extends protection to "owners" and the Fifth Amendment to "persons." The Sixth Amendment applies to the "accused," and the Seventh and Eighth Amendments do not limit their coverage to "citizens." Moreover, neither the word "citizen" nor the phrase "citizens of the United States" appears in the Bill of Rights.

I should now state the obvious. Limiting privileges or immunities to those rights that are possessed by citizens of the United States qua their status as national citizens results in an extremely narrow set of privileges or immunities. Indeed, a variation of this reading was adopted in the Slaughterhouse Cases-which are sometimes characterized as judicial 
nullification of the privileges or immunities clause.

\section{Privileges or Immunities that are Shared by Citizens of the United States: The Shared-Rights Interpretation}

There is, however, a third interpretation of the phrase "of citizens of the United States." Recall that we are assuming that the relevant rights are legal rights. The locution "privileges or immunities of citizens of the United States" might have been understood as referring to those rights that are shared by citizens of the United States. Thus, "No state shall make or enforce any law which shall abridge any privilege or immunity of a citizen of the United States" might have a different meaning than "No State shall make or enforce any law which shall abridge the privileges or immunities of citizens of the United States." The former expression could refer to the set of rights that results from adding the sets of legal rights that attach to each and every individual citizen. The later expression could refer to the set of rights that results from identifying the common members of the sets of legal rights that belong to individual citizens.

On the shared rights interpretation, the set of privileges or immunities is large, but it falls far short of all legal rights. For example, the right to own property and make contracts might have been shared by all citizens of the United States, but the right of particular persons in particular property or the rights conferred by a particular contract would not be shared. A core set of common law rights would have been shared by all $^{35}$ citizens, but to the extent that state law differed on the details of contract, tort, or property law, the zone of variation would be outside the set of shared rights.

The shared rights interpretation would seem to sanction incorporation of the Bill of Rights: all of the substantive rights protected by the Bill of Rights were shared by citizens of the United States.

\section{Resolving the Ambiguity Regarding the Meaning of "Of"}

Can the ambiguity regarding the meaning of "of" be resolved by original public meaning originalism - given the two assumptions (meaning to ordinary citizens only and interpretation solely)? That is surely a difficult question, and it is not the purpose of this Article to answer such questions. Theoretically, the method of approach would begin with an

35. "All" should probably be read as "almost" all, or perhaps "all" adult citizens who do not suffer from a legal disability, such as mental incapacity or conviction of a crime that results in a loss of rights otherwise available to adult competent citizens. 
investigation of linguistic practice. For example, it might be the case that the phrase "privileges or immunities of citizens of the United States" had acquired a quasi-idiomatic meaning: one of the three senses ("possessed by any," "in virtue of," or "shared by all") might be the standard meaning of the phrase. (This possibility seems very unlikely to me.) Or it might be the case that linguistic practice in the eighteenth century ruled out one of the possible senses identified here. (Again, this seems unlikely to me, but this is idle speculation without an examination of a massive amount of evidence.)

Originalist theory might allow for another route to the resolution of the ambiguity. Frequently, ambiguities in the linguistic meaning or semantic content of an utterance can be resolved by examining the context of utterance. In a given context, it may be clear that one of the possible senses of an utterance could not have been the sense in which the phrase would have been understood by competent speakers of English. That is, some senses of an ambiguous expression may become "absurd" in context. Given the theoretical commitments of original public meaning originalism, the relevant context would be what I have called "the publicly available context of constitutional utterance" - those features of the context of framing and ratification that would have been known to public at large at time of origin. Thus, if the constitutionalization of all legal rights would have been viewed as absurd, that reading of "of" might be ruled out. For example, the first sense of "of" identified above, the all-rights interpretation, might well have been considered absurd. Given the disagreement over the Slaughterhouse Cases, however, it may well be the case that neither the "in virtue of" nor the "shared by all" senses would have been viewed as absurd.

What does originalist theory prescribe in this situation? Again, the issue is complex and an adequate analysis would require an extended investigation. I believe that in the end, there are cases of what might be called "irreducible ambiguity." That is, there are cases when the original public meaning of a constitutional provision is ambiguous-even after the publicly available context of constitutional utterance is taken into account. As is the case with vagueness, this kind of ambiguity is not tantamount to indeterminacy. Originalist method might narrow the possibilities without fully resolving the question. At this point, the discovery of linguistic meaning has done all the work it can do. Interpretation exits the stage, and something else, constitutional construction, makes its entrance. 
If it were the case that the ambiguity between "in virtue of" and "shared by all" could not be resolved by interpretation, then our answer to the main question of this Part would be "negative." Given an ambiguity that cannot be resolved by interpretation and the assumption that interpretation must do all the work, originalist theory would suggest that the incorporation question is "undecidable" 36 in something like the formal sense of that term. Given our two assumptions (public meaning only and interpretation solely), incorporation could not be justified on originalist grounds.

\section{E. The Assumptions Revisited}

But what if we were to relax one or both of these assumptions? In the next Part of this Article, we shall examine the possibility that "public meaning originalism" could allow for technical meanings or terms of art. In the following Part, we shall consider the implications of constitutional construction for circumstances in which the linguistic meaning of the text is vague or irreducibly ambiguous.

\section{III. "PRIVILEGES OR IMMUNITIES" AS A TERM OF ART}

The phrase "privileges or immunities of citizens of the United States" might have been understood as "common parlance"-as having a meaning that is determined by the shared linguistic conventions of the linguistic community of speakers of American English in the midNineteenth Century. But what if this were not the case? What if "privileges" and "immunities" 37 were terms of art, with a technical meaning that

36. See Undecidable, Wikipedia, http://en.wikipedia.org/wiki/Undecidable.

37. It is possible that the larger phrase "privileges or immunities of citizens of the United States" had idiomatic or technical meaning as a whole phrase. Whether or not this was the case depends on the evidence, but there is evidence of usage of the whole phrase. For example, in Hepburn \& Dundas v. Ellzey, 2 Cranch 445, 451-52 (1805), lawyers for residents of the District of Colmbia argued: "It is true that the citizens of Columbia are not entitled to the elective franchise in as full a manner as the citizens of states. They have no vote in the choice of president, vice president, senators and representatives in congress. . . . But in every other respect the citizens of Columbia are entitled to all the privileges and immunities of citizens of the United States." And in 1835, Benjamin Butler, the Attorney General under Andrew Jackson, responded to efforts in Arkansas to organize proceedings to seek statehood:

No law has yet been passed by Congress which either expressly or impliedly gives to the people of Arkansas the authority to form a State government. . . . But I am not prepared to say that all proceedings on this subject on the part of the citizens of Arkansas will be illegal. They undoubtedly possess the ordinary privileges and immunities of citizens of the United States. Among these is the right of the people "peaceably to assemble and to petition the government for the redress of grievances." In the exercise of this right, the inhabitants of Arkansas may peaceably meet together in primary assemblies, or conventions chosen by 
would have been fully grasped by a linguistic subgroup (those learned in the law), but not fully understood by ordinary citizens? This Part addresses these questions in three stages: first, by considering the significance of technical meanings as a matter of originalist theory; second, by examining two candidates for the technical meaning of "privileges or immunities"; and third, by examining the implications of a technical meaning for the incorporation debate.

\section{A. The Division of Linguistic Labor}

How can originalists respond to the problem of constitutional terms of art-the use of "technical meanings"? How can "original public meaning originalism" embrace the idea that some of the provisions of the constitution might not have had "public meanings"? In approaching this question, it is important to recall that originalism is committed to recovery of the originalist linguistic meaning of the constitutional text. Linguistic meanings are determined by linguistic facts - and not by normative theories. The determination whether a given constitutional provision employed a technical meaning or term of art does not depend on our views of popular sovereignty or our beliefs about constitutional legitimacy. For example, if the phrase "letters of marquee and reprisal" was a term of art in late Eighteenth Century linguistic practice, then the semantic content of that phrase is given by its technical meaning-even if our beliefs about popular sovereignty lead us the conclusion that it

such assemblies, for the purpose of petitioning Congress to abrogate the Territorial government, and to admit them into the Union as an independent state. Right of the Territories to Become States, 2 Op. Att'y Gen. 726, 732-33 (1835). And President Jackson himself also used the whole phrase:

In the organization of the present temporary government, and its execution, I have steadily in few the securing to the inhabitants of the Floridas all the privileges and immunities guaranteed to them by the treaty.

The principle of these is the protection of their persons, property, and religion, until they shall be incorporated into the union, and become entitled to all the privileges and immunities of citizens of the United States.

Philo Ashley Goodwin, Biography of Andrew Jackson, President of the United States: Formerly Major General In the ARMy OF the United StATES 257 (1835), available at http://www .google.com/books?id=nHkEAAAAYAAJ.

In this Article, the aim is not to resolve this question, but rather to elucidate its theoretical dimension. If the whole phrase "privileges and immunities of citizens of the United States" had an idiomatic or technical meaning at the time the Fourteenth Amendment was adopted, then that meaning would be the relevant original public meaning for the purposes of originalist theory. 
would have been preferable for the framers to have employed a nontechnical term.

The solution to the problem of technical meanings is to recognize a division of linguistic labor. ${ }^{38}$ The intuitive idea is simple. When members of the general public encounter a constitutional term of art, their understanding of its meaning can be described as involving a process of deferral. Consider the following example. An ordinary citizen reads the phrase "letters of marquee and reprisal," and thinks, "Hmm. I wonder what that means. It sounds like technical legal language to me. If I want to know what it means, I should probably ask a lawyer or maybe a judge." That is, ordinary citizens would recognize a division of linguistic labor and defer to the understanding of the term of art that would be the publicly available meaning to those who were members of the relevant group and those who shared the understandings of the members of the relevant group. Blackstone put it this way: terms of art "must be taken according to the acceptation of the learned in each art, trade, and science." ${ }^{39}$

The technical meaning is (in a special sense) still a "public meaning." Given the division of linguistic labor, it is possible for ordinary citizens to recognize the meaningfulness of a term of art-even though they cannot themselves articulate even an approximate version of the criteria for correct application of the term. For example, we might say that the term "quark" has a public meaning, roughly "some sort of elementary particle that is defined by physics," even though very few members of the public could give a rough paraphrase of the definition or distinguish quarks from neutrinos. ${ }^{40}$

This solution to the problem of technical meanings requires either that each constitutional term of art refer us to a single group, or to a group of groups that share the same understanding of the term of art. For example, if both sailors and lawyers shared the same understanding of "letters of marquee and reprisal" then constitutional communication could succeed. If different groups had different understandings of the same phrase, constitutional communication could still succeed, assuming the publicly

38. The idea of a division of linguistic labor is usually attributed to Hilary Putnam. See Hilary Putnam, The Meaning of 'Meaning' in PhilosophicAl PAPERS, VOL. 2: Mind, LANGUaGe AND REALITY 227 (1985); see also Robert Ware, The Division of Linguistic Labor and Speaker Competence, 34 PHIL. STUD. 37, 37 (1978); Mark Greenberg, Incomplete Understanding, Deference, and the Content of Thought (UCLA Sch. of Law Research Paper No.07-30), available at http://ssrn.com/abstract=1030144.

39. William Blackstone, COMmentaries on the LaWS OF ENGLAND *59 (W.S. Hein \& Co. reprint 1992) (1768).

40. Compare Quark, Wikipedia, http://en.wikipedia.org/wiki/Quark with Neutrino, Wikipedia, http://en.wikipedia.org/wiki/Neutrino. 
available context of constitutional utterance allowed resolution of the resulting ambiguity. For example, if the publicly available context of constitutional utterance made it clear that the relevant sense of "letters of marquee and reprisal" was the legal sense, then the linguistic practices of lawyers (and not of sailors) would determine the relevant meaning of the term.

At this point, it might be argued that allowing for constitutional terms of art is inconsistent with popular sovereignty as a normative justification for originalism. Full consideration of that argument is itself a large topic deserving of extended treatment, but on this occasion I can only offer a few brief remarks.

First, it is not clear that the deployment of constitutional terms of art is inconsistent with popular sovereignty. Reconciliation might occur via several routes. For example, it might be argued that democratic legitimacy requires only that the term of art be publicly accessible through reasonable effort. Most participants in the ratification process might rely on the fact that a few participants have ascertained that the technical meaning did not conceal a secret meaning that would not have survived full public disclosure: this seems especially plausible with respect to complex provisions with limited effects. Or it might be argued that the Constitution as a whole can retain democratic legitimacy even if there are particular provisions that lack public meanings.

Second, it is not clear that popular sovereignty theory provides the best or only justification for originalism. It might be the case that adherence to original meaning is justified by rule of law concerns-even if an important constitutional provision were undemocratic because of its use of technical language. Third, even if popular sovereignty theory warranted the judicial nullification of the original linguistic meaning of a technical term in the Constitution, it might nonetheless be important to understand what meaning was being rejected. The actual linguistic meaning of the provision might, for example, be relevant to the construction of an artificial "public meaning" for the purposes of articulating constitutional doctrine.

\section{B. "Privileges or Immunities" as a Term of Art}

Once again, this Article makes no claims about the original meaning of the privileges or immunities clause. On this occasion, the aim is simply to explicate the implications of originalist theory for such claims. Nonetheless, it may be helpful to examine some of the possible 
"technical meanings" in order to make the explication of abstract theory both clearer and more determinant.

\section{Corfield v. Coryell}

The legislative history of the Fourteenth Amendment contains a variety of references of Justice Bushrod Washington's opinion in Corfield v. Coryell, ${ }^{41}$ a Circuit Court opinion interpreting the privileges and immunities clause of Article IV. That clause provides:

The Citizens of each State shall be entitled to all Privileges and Immunities of Citizens in the several States. ${ }^{42}$

Corfield offered the following gloss on the meaning of the phrase "privileges and immunities":

The inquiry is, what are the privileges and immunities of citizens in the several states? We feel no hesitation in confining these expressions to those privileges and immunities which are, in their nature, fundamental; which belong, of right, to the citizens of all free governments; and which have, at all times, been enjoyed by the citizens of the several states which compose this Union, from the time of their becoming free, independent, and sovereign. What these fundamental principles are, it would perhaps be more tedious than difficult to enumerate. They may, however, be all comprehended under the following general heads: Protection by the government; the enjoyment of life and liberty, with the right to acquire and possess property of every kind, and to pursue and obtain happiness and safety; subject nevertheless to such restraints as the government may justly prescribe for the general good of the whole. The right of a citizen of one state to pass through, or to reside in any other state, for purposes of trade, agriculture, professional pursuits, or otherwise; to claim the benefit of the writ of habeas corpus; to institute and maintain actions of any kind in the courts of the state; to take, hold and dispose of property, either real or personal; and an exemption from higher taxes or impositions than are paid by the other citizens of the state; may be mentioned as some of the particular privileges and immunities of citizens, which are clearly embraced by the general description of privileges deemed to be fundamental: to which may be added, the elective franchise, as regulated and established by the laws or constitution of the state in which it is to be exercised. 43

This passage suggests that the "privileges and immunities" of Article IV are a subset of the general class of all privileges and immunities - those which are "fundamental," "belong of right to the citizens of all free governments," and "have, at all times, been enjoyed by the citizens of the several states." It then offers a list of particular rights that are included in the list.

From the perspective of originalist theory, it is not clear what is going

41. Corfield v. Coryell, 6 F. Cas. 546 (C.C.E.D. Pa. 1823) (No. 3,230).

42. U.S. ConsT. art. IV, $\$ 2$.

43. Corfield, 6 F. Cas. at 551. 
on in Corfield. There opinion does not define the relevant terms ("privilege" and "immunity"). Instead, it assumes that the phrase "privileges and immunities" is understood, and then suggests that the relevant subset contains only those privileges and immunities that are "in their nature fundamental." This move might be justified on the ground that only the fundamental privileges and immunities are privileges and immunities of citizens in the several states. Or this might be considered a narrowing construction of a constitutional provision that otherwise would be impracticably broad. But whatever the rationale of Corfield, it might be argued that the Corfield gloss established a technical meaning for the phrase "privileges and immunities" that would have been recognized as the meaning of the Fourteenth Amendment "privileges or immunities" clause by those learned in the law at the time of its framing and ratification.

Something more needs to be said about the possibility that Corfield established a technical legal meaning for "privileges" and "immunities." To simplify, we can imagine a four-stage sequence by which the phrase "privileges or immunities of citizens of the United States" acquired its "original linguistic meaning." At stage one, we have the conventional semantic meaning of the "privileges and immunities" clause of Article IV. This meaning is simply the meaning of the individual words and phrases as combined by the rules of grammar and syntax at the time the original constitution was framed and ratified. At stage two, the "privileges or immunities clause" of Article IV is given an authoritative construction by the Supreme Court in Corfield. At stage three, that authoritative construction is absorbed by the linguistic subcommunity that consists of those learned in the law (lawyers, judges, and others), resulting in the words "privilege" and "immunity" acquiring a new technical meaning in legal discourse. At stage four, that technical meaning is assumed in the framing, ratification, and subsequent interpretation of the Fourteenth Amendment. The result is that the terms "privilege" and "immunity" had one linguistic meaning at the time Article IV was framed and ratified, and a different, but related meaning at the time the same words were used in the Fourteenth Amendment.

On this view, the terms "privileges" and "immunities" when used in appropriate contexts-including discussions of constitutional lawwould be terms of legal art or more particularly terms of art in American constitutional law. Ordinary citizens might not be able to produce anything like the Corfield gloss if asked for the meaning of the phrase, 
but they might recognize that technical language was being employed. On this view, "privileges" and "immunities" are like "quarks": ordinary citizens may not be able to define them, but they recognize that they have technical meanings that are understood by experts.

\section{Blackstone}

There are other indications that the words "privileges" and "immunities" might have had technical meanings, even before the words were used in Article IV. In his Commentaries, Blackstone used the terms "privilege" and "immunity" as terns of art in the theory of the common law:

Thus much for the declaration of our rights and liberties. The rights themselves thus defined by [Magna Carta and other foundational] statutes, consist in a number of private immunities; which will appear, from what has been premised, to be indeed no other, than either that residuum of natural liberty, which is not required by the laws of society to be sacrificed to public convenience; or else those civil privileges, which society hath engaged to provide, in lieu of the natural liberties so given up by individuals. These therefore were formerly, by inheritance or purchase, the rights of all mankind; but, in most other countries of the world being now more or less debased and destroyed, they at present may be said to remain, in a peculiar and emphatical manner, the rights of the people of England. And these may be reduced to three principal or primary articles; the right of personal security, the right of personal liberty; and the right of private property: because as there is no other known method of compulsion, or of abridging man's natural free will, but by an infringement or diminution of one or other of these important rights, the preservation of these, inviolate, may justly be said to include the preservation of our civil immunities in their largest and most extensive sense. ${ }^{44}$

Blackstone used the term "immunities" to describe what we would call "natural rights" or "rights of political morality." His concept of "privileges" or "civil privileges" corresponds to the modern notion of a legal right.

Blackstone's Commentaries and various American editions thereof certainly constituted part of the technical knowledge of those learned in the law in the Nineteenth Century. It might be argued that Blackstone's usage - equating immunities with natural rights and privileges with legal rights that substituted for (or protected) natural rights - either created or was evidence of common law terms of art that provided the relevant technical sense for these terms in Article IV and subsequently the Fourteenth Amendment.

Although Bushrod Washington's formulation in Corfield v. Coryell is not identical to Blackstone's, it is possible that these definitions can be

44. Blackstone, supra note 39, at*128-29 (emphasis added); see also Eric R. Claeys, Blackstone's Commentaries and the Privileges or Immunities of United States Citizens: A Modest Tribute to Professor Siegen, 45 SAn Diego L. Rev. 777, 781-82, 784 (2008). 
reconciled. Corfield doesn't define "privilege" or "immunity" - it assumes some prior or already understood definition or usage. The use of "fundamental" in Corfield could be reconciled with the notion of "natural liberty" in Blackstone. Corfield's list of privileges or immunities begins with "Protection by the government; the enjoyment of life and liberty, with the right to acquire and possess property of every kind" which seems to echo Blackstone's three categories: "the right of personal security, the right of personal liberty; and the right of private property."

\section{The Implications for Incorporation}

Assuming arguendo that the "privileges or immunities" clause had a technical meaning along the lines suggested by Blackstone and/or Corfield, what would be the implications for the incorporation debates? The most obvious implication is that the specific list of rights contained in the Bill of Rights would have no special per se status as privileges or immunities. That is not to say that these rights would not qualify as "natural liberties" or as "fundamental." But it would suggest that inclusion in the Bill of Rights would not automatically qualify a given right as a privilege or immunity of citizens of the United States. Inclusion of a right in the Bill of Rights might, however, be relevant (epistemically) to the inquiry as to whether the right was "fundamental" or a "civil privilege" that protected an underlying "natural liberty." The fact that the framers of the Bill of Rights included a particular right in the Bill of Rights is evidence that they considered the right to be fundamental, and their opinions about this matter might affect our deliberations. At a minimum, the inclusion of a right in the Bill of Rights might create a presumption (even if it were only a "bursting bubble") in favor of inclusion of the right. At a maximum, we might accord the framers and ratifiers of the Fourteenth Amendment epistemic authority over this question, concluding that our deliberations about the question whether these rights were truly fundamental would be more likely to issue in correct outcomes if we deferred to their opinions.

Of course, it would not follow from this that the Bill of Rights would constitute an exhaustive list of the "privileges or immunities of citizens of the United States." Other rights might be included as well-including general rights to acquire, own, and alienate private property, to form and enforce contracts, to the protection of the state against violence, to selfdefense, and so forth. Further complications become apparent at this stage of the analysis. Suppose, for example, that the technical meaning of immunity was "natural right" and of privilege "a legal right that protects or 
substitutes for a natural right." What then are "natural rights" (or "natural liberties" to use Blackstone's phrase)? What are the implications for originalist theory if we believe that Eighteenth Century understandings of natural or fundamental rights were in error? Or what if we conclude that the idea of a "natural right" is simply a mistake - that there are no real or actual entities that correspond to the eighteenth century conception of a natural right? Should judges then resort to a "saving" or "mending" construction of the relevant provision? Some of these questions will be discussed in Part V below, but at this stage, we return to the assumption made in Part II above, that the question of incorporation must be addressed by constitutional interpretation without the aid of constructions.

\section{CONSTRUCTION OF THE PRIVILEGES OR IMMUNITIES Clause}

In Part II, we assumed (for the purposes of clarity and precision in exposition) that the implications of originalist theory for incorporation could be addressed solely as a matter of constitutional interpretation. That is, we assumed that the relevant question was whether the linguistic meaning of the constitutional text either required or forbade incorporation. Although that assumption is useful for the purpose of this Articleexploration of the interaction of incorporation with originalist theory-it may obscure rather than illuminate the substance of the incorporation debate. This would be the case, for example, if the text underdetermines the answer to the question whether the rights enumerated in the Bill of Rights are among the privileges or immunities of citizens of the United States. In this Part, we investigate the implications of constitutional construction for the question whether the privileges and immunities clause supports incorporations.

We can begin by revisiting the interpretation-construction distinction, and then proceed to consider its implications for incorporation.

\section{A. The Interpretation-Construction Distinction Revisited}

What is the difference between "constitutional interpretation" and "constitutional construction?"45 Absent a thorough familiarity with the history of the law of contracts, trusts, or wills, or a deep knowledge of contemporary constitutional theory, some readers may assume that these

45. See generally Mark K. Glasser \& Keith A. Rowley, On Parol: The Construction and Interpretation of Written Agreements and the Role of Extrinsic Evidence in Contract Litigation, 49 BAYLOR L. REv. 657, 661-63 (1997); Note, Choice of Law Rules for the Construction and Interpretation of Written Instruments, 72 HARV. L. REV. 1154, 1155$56(1959)$. 
two terms are synonyms. Many authors use "interpretation" and "construction" more or less interchangeably. ${ }^{46}$ In fact, the distinction between interpretation of the linguistic meaning of legal texts and the construction of legal rules from that linguistic meaning has a long history in Anglo-American law. ${ }^{47}$ Elaborating on the very tentative formulation offered above, ${ }^{48}$ we might use the following definitions:

Interpretation: The activity of determining the linguistic meaning or semantic content - of a legal text.

Construction: The activity of translating the semantic content of a legal text into legal rules, paradigmatically in cases where the meaning of the text is vague.

We interpret the meaning of a text, and then we construct legal rules to help us apply that linguistic meaning to particular fact situations.

Courts and legal theorists have deployed the distinction between interpretation and construction in a variety of legal contexts, including contract law. In a contracts case, for example, the Iowa Supreme Court stated, "Interpretation involves ascertaining the meaning of contractual words; construction refers to deciding their legal effect." 49

We have already noted the connection between the interpretationconstruction distinction and the vagueness-ambiguity distinction. Characteristically, interpretation resolves ambiguity and construction creates subsidiary rules that resolve vagueness. In most cases, interpretation resolves ambiguity because usually there is a linguistic fact of the matter about the semantic meaning of a text given the context of utterance: words that are ambiguous without context usually become unambiguous once the context of utterance is considered. This fact is a simple

46. See, e.g., Michael W. Mullane, Statutory Interpretation in Arkansas: How Should a Statute be Read? When is it Subject to Interpretation? What our Courts Say and What they Do, 2004 ARK. L. NOTES 85, 89 n.22 (2004) (“"Interpretation” and "construction" will be treated as synonyms in this paper."); BRYAN A. GARNER, A Dictionary of Modern Legal Usage, 462 (2nd Ed. 1995); Gary E. O'Connor, Restatement (First) of Statutory Interpretation, 7 N.Y.U. J. LEGIS. \& PUB. POL'Y 333, 335 n.5 (2004) ("This article treats the terms "statutory interpretation" and "statutory construction" as interchangeable synonyms.").

47. Francis LiEBER, LeGAl AND POLITICAL HERMENEUTICs 11, 44 (1880), available at $\mathrm{http}$ ///books .google.com/books?id=tE4uAAAAIAAJ\&printsec=titlepage\&dq=lieber+legal thermeneutics.

48. See supra text accompanying note 20 .

49. Fashion Fabrics of Iowa, Inc. v. Retail Inv. Corp., 266 N.W. 2d 22, 25 (Iowa 1978). 
consequence of the ability of humans to communicate effectively: most of the time speakers and writers aim at avoiding irresolvable ambiguity and listeners and readers are skilled at deciphering ambiguities by attending to contextual clues.

The relationship between ambiguity, context, and interpretation can be clarified by examples. Consider once again the ambiguous word "cool." In the context, "That refrigerator is running very cool-let's check the thermostat," the ambiguity disappears. Likewise, if someone says, "Miles Davis was a pioneer of cool jazz," we know that the intended sense is not temperature related. This same point can be illustrated with examples from constitutional law. For example, the phrase "United States" in the United States Constitution refers to the nation composed of fifty states in North American and various territories; it does not refer to other political entities that have been called the United States, such as the United States of Belgium, the United States of Mexico or the United States of Brazil.

Characteristically, interpretation resolves ambiguity, but in the usual case, construction resolves vagueness. Interpretation is inapt as a method for resolving vagueness, because interpretation (the determination of linguistic meaning or semantic content) cannot do the required work. When a word or phrase has a linguistic meaning that is vague, then interpretation runs out. If the linguistic meaning is vague, then vagueness is the result of interpretation and not a problem to be solved by interpretation. When interpretation exits the stage, then construction makes its entrance. Construction allows us to draw a line-making the vague provision more specific-or gives us a decision procedure, such as a procedure that allows case-by-case resolution of the vagueness.

In the discussion that follows, we will investigate the possibility that the constitutional decision whether to incorporate the Bill of Rights via the privileges or immunities clause must or should be made via a process of constitutional construction.

\section{B. Incorporation and Vagueness}

Is the privileges or immunities clause vague? On some readings of the clause, it may be. For example, if the meaning of "of" is "shared by citizens" then there may be borderline cases - rights that are recognized by almost all of the states and therefore are shared by most but not all citizens: it might be the case that most but not all states required indictment by a grand jury at the time the privileges or immunities clause was adopted. The Fifth Amendment's command that "No person shall be held to answer for a capital, or otherwise infamous crime, unless on a presentment or indictment of a grand jury," might serve as the basis for a construction of "privileges or immunities" that included the right. 
Similarly, if "privileges or immunities" were "fundamental" rights or "natural liberties," there might be borderline cases - rights for which the question whether they are fundamental vel non has no determinate answer. If this were the case, then construction would be required. We might adopt a rule of construction that afforded decisive weight to the fact that that a right was included in the Bill of Rights. For example, it might be argued that the right against self-incrimination is not clearly fundamental, but that as a matter of constitutional construction, it should be counted as among the privileges and immunities of citizens of the United States.

There is another way in which the privileges or immunities clause might be vague. Even if it is clear that a particular abstract right is a privilege or immunity of citizens of the United States, that abstract right may itself be vague. For example, suppose that freedom of speech is clearly one of the privileges or immunities of citizens of the United States. Nonetheless, the question whether a particular state law violates the freedom of speech may itself involve a borderline case that could reasonably be resolved either way. Constitutional doctrine might resolve these borderline cases one way if the actor was the federal government and another way if the alleged violator was a state or local government. But this has not been the usual rule of constitutional doctrine (in the current doctrinal environment in which incorporation is accomplished via the due process clause). Under the regime of selective incorporation, some but not all of the provisions of the Bill of Rights are applied to the states, but once a provision is "incorporated" then all of the applicable rules of federal constitutional doctrine are applied as well. This result would be remarkably difficult to justify as a matter of constitutional interpretation: the specific contours of first amendment doctrine are even less plausibly attributed to the privileges or immunities clause than they are to the First Amendment itself. But this rule might make eminent sense as a rule of constitutional construction - for a variety of reasons. ${ }^{50}$

50. We can imagine several reasons for incorporating the details of federal Bill-ofRights doctrine in construction of the Fourteenth Amendment privileges-or-immunities clause. For example, this might be done as a matter of judicial economy-the federal doctrine has already been developed. Or it might be done for reasons of fairness - those persons whose rights are invaded by state governments should be treated similarly to those rights that are invaded by the federal government. Of course, the claim in this Article is not that these arguments are correct. They are offered solely for the purpose of illustrating the way in which wholesale incorporation of federal Bill-of-Rights doctrine 


\section{Incorporation and Irreducible Ambiguity}

Many problems of constitutional ambiguity can be resolved by constitutional interpretation - the public context of constitutional utterance may be sufficient to resolve questions about the public meaning of a text with more than one acontextual conventional semantic meaning. But it is at least theoretically possible that there are cases of irreducible constitutional ambiguity.

At an abstract level we might distinguish between two distinct types of irreducible ambiguity. We can use the phrase "epistemic ambiguity" to refer to situations in which the original public meaning (the meaning at the time a constitutional provision was framed and ratified) could be resolved based on the contextual clues and linguistic knowledge available to the public of that time, but in which the passage of time has resulted in the loss of some of the essential information. For example, contemporary knowledge of archaic patterns of usage may be not be sufficiently rich and detailed to permit disambiguation of utterance that depend on subtle distinctions among the various senses of a given word. Or information about the context of constitutional utterance may have been lost: for example, the publicly available context of constitutional utterance may include information conveyed orally that was never recorded in written texts, or all of the texts that recorded the information may have been lost.

Epistemic ambiguity can be contrasted with what we can call "ontological ambiguity." It may be the case that some constitutional provisions were irreducibly ambiguous for the public at the time of origination. There could be several reasons why this might be the case, including the following two.

First, it might be the case that the framers of a particular provision deliberately chose to employ ambiguous language. Such deliberate ambiguity might be chosen in order to achieve sufficient votes to propose or to secure ratification of a controversial provision.

Second, it might be the case that the framers of a constitutional provision were unaware of an ambiguity in the language that they chose. This might result from partial linguistic isolation of the framers of a particular provision from the larger linguistic community. For example, members of Congress who draft a constitutional amendment might mutually reinforce one another in assuming that the intended meaning of a particular expression is the unambiguous public meaning. This phenomenon might involve path dependence. For example, if a potential ambiguity

must be justified as a construction (as distinguished from an interpretation) of the Fourteenth Amendment. 
goes unnoticed early in the drafting process, the interaction among drafters might reinforce the intended meaning, so that the ambiguity becomes "invisible" or sounds "absurd" among the group of drafters. Such linguistic isolation may be reinforced in circumstances where there are political reasons or practical reasons to limit the drafting process to "insiders."

If there were provisions of the constitution that were irreducibly ambiguous, this fact would present a challenge for originalist theory. What should an originalist say when constitutional interpretation yields the conclusion that a particular constitutional provision has one of two potential meanings? The appropriate response might depend on the question whether the ambiguity at hand was epistemic or ontological. In the case of epistemic ambiguity, some originalists might take the position that contemporary constitutional actors should adopt the interpretation that is most likely to be correct, even if the level of certainty associated with that judgment is very low.

But in the case of ontological ambiguity, this option is not available. In such cases, ambiguity is the bottom line of interpretation. The semantic content or linguistic meaning of the provision simply is ambiguous as a matter of fact. In such cases, construction is required to apply the rule in a determinate fashion to any case in which the ambiguity makes practical difference. (There may be many cases in which the ambiguity would not make a difference-the same part would win under either interpretation.) How might such construction proceed? There are many possibilities. One might take precedent or historical practice as influential or even decisive-in cases in which such practice or precedent would resolve the ambiguity. Keith Whittington suggests that construction should generally be guided by a principle of deference to the political branches, and that construction outside the judiciary is a political process. ${ }^{51}$

Randy Barnett suggests construction should be guided or constrained by a principle of constitutional legitimacy that requires reasonable assurances of just outcomes: this mode of construction might require judges to make substantive judgments about the justice of alternative constructions. ${ }^{52}$

None of this suggests any particular position on incorporation under the Bill of Rights via the privileges or immunities clause. Rather, the

51. See WhitTINGTON, CONSTITUTIONAL INTERPRETATION, supra note 20; WhitTington, CONSTITUTIONAL CONSTRUCTION, supra note 20, at 6.

52. See BARNETT, supra note 20 , at 126. 
point of this discussion is to highlight the possibility that irreducible ambiguity in the meaning of the privileges or immunities clause might require constitutional construction. When it comes to specific methods of constitutional construction, many or most originalists may agree that construction should be bounded by original meaning-at least in the absence of extraordinary circumstances.$^{53}$ But originalists disagree about the proper approach to constitutional construction within those bounds. That is hardly surprising. The content of theories of constitutional construction is outside the core commitments of originalism to the fixation thesis and the contribution thesis.

\section{FAILURE OF CONSTITUTIONAL COMMUNICATION}

One final topic remains before we conclude. What, if anything, might originalists say about the possibility that some provisions of the constitution lack original meaning altogether? Could an originalist reach the conclusion that the privileges or immunities clause is an inkblot? And how might originalists respond to this possibility?

\section{A. Failure of Constitutional Communication in Theory}

The Constitution contains many provisions that are vague. And it is not implausible to believe that the Constitution contains some provisions that are irreducibly ambiguous as between a constrained set of possible original meanings. But could an originalist accept the possibility that there are provisions of the constitution that are literally meaningless? Of course, it is not difficult to imagine possible constitutions that contain meaningless provisions: "Amendment 57: In the event of purple mellifluousness, the mome raths shall grabe." Or if you think you understand that, try this: "Amendment 58: k3m 0ck dk1cto." Or even this $\rightarrow$.

53. Of course, "extraordinary circumstances" needs to be defined or clarified. Some of the relevant considerations are discussed in the next Part of this Article. See infra Part 0, "V. Failure of Constitutional Communication," p. 442. 
But the United States Constitution does not contain gibberish, meaningless strings of symbols, or inkblots. It does, however, contain provisions that some readers have characterized as the functional equivalent of inkblots. When asked about the Ninth Amendment in confirmation hearings, Judge Bork responded:

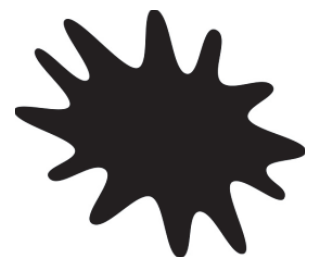

I do not think you can use the Ninth Amendment unless you know something of what it means. For example, if you had an amendment that says "Congress shall make no" and then there is an inkblot and you cannot read the rest of it and that is the only copy you have, I do not think the court can make up what might be under the inkblot if you cannot read it. 54

And Bork has made a similar suggestion with respect to the privileges or immunities clause. ${ }^{55}$ Pace Bork, ${ }^{56}$ it seems unlikely that there are any cases of catastrophic failure of constitutional meaning in the actual Constitution of the United States. Constitutional provisions are drafted with care, and it would be extraordinarily unusual for a constitutional provision with no meaning at all to survive the process of framing and ratification. More plausible is the possibility that a constitutional provision would be radically ambiguous - with multiple meanings that would have widely divergent implications for constitutional practice.

\section{B. The (Hypothetical) Case for the Failure of the Privileges or Immunities Clause}

In the case of the privileges or immunities clause, it is at least conceivable that the clause suffers from multiple and complex forms of irreducible ambiguity. Suppose, for example, that the drafters mistakenly believed that the public would generally recognize the phrase "privileges or immunities of citizens of the United States" as a term of art, but in

54. Nomination of Robert H. Bork to be Associate Justice of the Supreme Court of the United States: Hearings Before the S. Comm. on the Judiciary, 100th Cong. 224 (1987) (statement of Judge Robert H. Bork); see also Kurt T. Lash, Of Inkblots And Originalism: Historical Ambiguity and the Case of the Ninth Amendment, 31 HARV. J.L. \& PuB. POL'Y 467, 469 (2008).

55. Robert H. Bork, The Tempting OF America 166 (1990).

56. On the meaning of the Ninth Amendment, see Randy E. Barnett, The Ninth Amendment: It Means What It Says, 85 Tex. L. Rev. 1 (2006); Lash, supra note 54, at 467. 
fact this recognition was highly inconsistent, with some readers assuming that "privileges or immunities" simply meant "rights" and others assuming that it carried a technical legal meaning. It might further be the case that some readers of the phrase would believe that the meaning of "of" is "by virtue of" and other readers would believe that the relevant sense of "of" was "shared by all." In these circumstances, the meaning of the clause might be so ambiguous that we might be tempted to say that there had been a failure of constitutional communication. If the privileges or immunities clause could be either a natural rights clause or shared-rights clause or a clause that is limited to those rights that citizens possess by virtue of their national citizenship, the different senses corresponding to constitutional doctrines that have little in common with each other.

If the scenario hypothesized in the prior paragraph were actually the case (and I am not suggesting that it is), then we might be tempted to characterize the privileges or immunities clause as a case of the failure of constitutional meaning.

\section{Incorporation as a Mending Construction}

Failures of constitutional meaning require constitutional construction. If a given constitutional provision has no linguistic meaning or that meaning is radically ambiguous, then the translation of semantic content into legal content cannot proceed mechanically or automatically. A constitutional construction of some kind is required; without a construction, constitutional actors would have no basis for the application of the provision to a particular case. So the question inevitably would arise: "how should the constitution be construed if there has been a failure of constitutional communication?"

Once again, there are various possibilities. One of these would simply be to declare the meaningless clause to be "null and void," but this is not the only alternative. Another possibility is to adopt the constitutional equivalent of a "saving construction." ${ }^{57}$ Originalists are generally committed to the principle that constitutional constructions must be consistent with the semantic content or linguistic meaning of the Constitution. A construction that is inconsistent with the original meaning of the constitutional text might be labeled an amending construction - and both originalist theory and conventional legal practice agree that that judges do not have the authority to amend the Constitution.

But there may be some cases in which the commitment to the constitution requires a construction that is inconsistent with original meaning of the text. Here is a science fiction example: suppose that a plague resulted in

57. Adrian Vermeule, Saving Constructions, 15 GEO.L.J. 1945 (1997). 
the death of all persons who were 35 years of age or older. The text of the Constitution would result in the conclusion that no one could constitutionally serve as the President of the United States, but were this bizarre (and from my perspective terribly unfortunate) turn of events to transpire, constitutional actors would surely adopt a construction of the Constitution that preserved constitutional government. They would adopt a "mending construction" of Article II that repaired the tear in the constitutional fabric.

The notion of a mending construction might be adapted to the problem of failures of constitutional meaning. In the case of the privileges or immunities clause, the doctrine of incorporation might be justified as such a mending construction. It might be argued that the privileges or immunities clause simply fails to provide sufficient guidance for identification of the privileges or immunities of citizens of the United States. One might then label the provision an Inkblot, and simply write it out of the constitution altogether-this might be Judge Bork's preferred alternative. Or one might adopt a construction of the privileges and immunities clause that preserves its formal existence, but defines "privileges and immunities" so narrowly that the clause will provide an absolute minimum of constraint on state governments - this may be the approach adopted by the majority in the Slaughterhouse Cases. Or one might go a different route and adopt the doctrine of incorporation as a mending construction-not because incorporation is required by the linguistic meaning of the text, but because this construction is supported by a variety of concerns - furthering the purposes of the clause, conforming to the expectations of some or many of those who participated in its framing and ratification, limiting judicial discretion, achieving justice, and so forth.

\section{CONCLUSION: WHY INCORPORATION MATTERS FOR ORIGINALISTS}

As a practical matter, the doctrine of incorporation is of great practical significance. If originalist theory were to provide decisive reasons for either affirming or rejecting incorporation, those reasons would certainly imply that originalism has "bite." Some originalists may believe that incorporation should be rejected on originalist grounds; others may believe the opposite. In this Article, I have suggested that originalists should be interested in debates over incorporation for an additional and quite different reason. Incorporation puts originalism through the wringerit forces originalists to consider a complex set of issues that push the 
limits of originalist theory. Originalism must confront the tension between their commitments to "normal meanings" and a constitution that contains technical terms. Originalism must address the relationship between originalist interpretation and constitutional construction. And originalism may be required to give a well-theorized account of the failure of constitutional meaning. 